\title{
Influence of immersion time of denture cleansers on the surface roughness of resilient denture liners
}

\author{
Influência do tempo de imersão de limpadores químicos \\ sobre a rugosidade de superfície de reembasadores resilientes \\ para próteses removíveis
}

\begin{abstract}
Purpose: The objective of this study was to evaluate the effect of different immersion times in denture cleansers on surface roughness (SR) of two resilient denture liners (RDL) after the cleanliness of Candida albicans biofilm.

Methods: Poly(methyl methacrylate) (PMMA) resin discs $(10 \times 1.5 \mathrm{~mm}$ ) were relined with a $1.5 \mathrm{~mm}$ layer of RDL (PMMA or silicone-based). The initial SR of each specimen was measured and C. albicans biofilm was developed for $48 \mathrm{~h}$. Subsequently, the discs were randomly assigned for one of four cleansing treatments $(n=8)$ : two alkaline peroxide (soaking for 3 or $15 \mathrm{~min}$ ), $0.5 \%$ sodium hypochlorite $(10 \mathrm{~min}$ ) or distilled water as control $(15 \mathrm{~min})$. After the treatments, the SR was measured again. Data were analyzed by ANOVA and the Tukey post-hoc test $(\alpha=0.05)$. Results: No differences were found between the cleansing treatments evaluated $(P>0.05)$. The PMMA-based liner exhibited higher SR than silicon-based $(P<0.001)$; however, both liners showed higher SR after the treatments compared with the baseline values $(P<0.001)$.

Conclusion: Within limitations of this study, it can be concluded that the surface roughness of RDL increased after the immersion in denture cleansers, independently of the time of immersion.
\end{abstract}

Key words: Denture liners; denture cleansers; disinfection

\section{Resumo}

Objetivo: $\bigcirc$ objetivo deste estudo foi avaliar o efeito de diferentes tempos de imersão em limpadores químicos sobre a rugosidade de superfície (RS) de reembasadores resilientes após a simulação da limpeza de biofilmes de Candida albicans.

Metodologia: Discos (10x1,5 mm) de poli(metilmetacrilato) (PMMA) foram cobertos com uma camada de 1,5 mm de reembasador resiliente (a base de PMMA ou silicone). A RS inicial de cada espécime foi mensurada e biofilmes de C. albicans desenvolvidos por $48 \mathrm{~h}$. Em seguida, os espécimes foram submetidos aleatoriamente a um dos tratamentos $(n=8)$ : duas soluções alcalinas a base de peróxido (imersão por 3 ou $15 \mathrm{~min}$ ), hipoclorito de sódio a $0.5 \%$ (10 min) ou água destilada como grupo controle (15 min). Após o tratamento, a RS foi mensurada novamente. Os resultados foram analisados por ANOVA e teste Tukey $(\alpha=0,05)$.

Resultados: Não houve diferença estatística entre os tratamentos $(P>0,05)$. $O$ reembasador a base de PMMA apresentou maior RS que os de silicone $(P<0,001)$; entretanto, ambos apresentaram um aumento da RS após os tratamentos $(P<0,001)$.

Conclusão: Dentro das limitações deste estudo, conclui-se que a RS dos reembasadores resilientes aumenta após a imersão em limpadores químicos, independentemente do tempo de imersão.

Palavras-chave: Reembasadores; limpador de prótese; desinfecção

\author{
Plinio Mendes Senna a \\ Ana Paula Coelho Vieira b \\ Bruno Sales Sotto-Maior a \\ Wander José da Silva a \\ Altair A. Del Bel Cury a
}

- Department of Prosthodontics and Periodontology, Piracicaba Dental School, State University of Campinas, Piracicaba, SP, Brazil

b Department of Prosthodontics, School of Dentistry, State University of Amazonas, Manaus, AM, Brazil
Correspondence:

Piracicaba Dental School, State University of Campinas Departament of Prosthodontic and Periodontology P.O. Box 52

Piracicaba, SP - Brazi

13414-903

E-mail: altcury@fop.unicamp.br

Received: December 20, 2010

Accepted: January 28, 2011

Conflict of Interest Statement: The authors state that there are no financial and personal conflicts of interest that could have inappropriately influenced their work.

Copyright: (C) 2011 Senna et al.; licensee EDIPUCRS. This is an Open Access article distributed under the terms of the Creative Commons AttributionNoncommercial-No Derivative Works 3.0 Unported License. 


\section{Introduction}

The use of resilient denture liner (RDL) has increased in clinical practice. It provides relief for sharp bony undercuts or extreme sensitivity due to submucosal exposure of the inferior alveolar nerve (1). It also absorbs the occlusal loading during mastication, protecting the implants in the post-operatory period (2).

RDL may be fabricated from poly(methyl methacrylate) (PMMA) resin or silicone rubber. Although siliconebased RDL is more elastic and shows higher resistance to dimensional changes than the PMMA-based, it may present bond failure between the RDL and the denture base resin (2). On the other hand, PMMA RDL demonstrates better abrasion resistance and adhesion to denture base resin (3). Despite of these materials show excellent tissue tolerance and are widely used, they have shorter life expectancies than traditional denture base resins (4), presenting dimensional changes while the plasticizing agent leaches out from the RDL (3). These surface alterations lead to the occurrence of oral candidosis due to an easy RDL colonization and tissue infection by Candida spp. (5).

A higher adherence of microorganisms is noted on RDL than PMMA denture base resins, due to the presence of irregularities and porosities on its surface, which harbor microorganisms making harder their removal (6). The biofilm control of RDL should not be done by brushing due to the risk of surface damaging. Thus, denture cleanser solutions are the chosen method for biofilm control (7). These denture cleansers are classified according to their mode of action or main components, and they are generally alkaline peroxides containing enzymatic activity, which is responsible for the dislodging of food debris and the biofilm (8). Their effectiveness are related to the immersion time of the denture in the solution; however, in the healthmarket, the manufacturers recommend different immersion times for similar products.

Although some studies have acessed the effect of denture cleansers on the surface of RDL, doubts are persistent, considering that the surface deterioration of RDL is found to be more greatly influenced by the time of immersion than by the type or composition of the denture cleansers (9).

Therefore, the aim of this study was to evaluate the effect of different immersion times (recommended by the denture cleanser manufacturer) on surface roughness (SR) of two resilient denture liners (RDL) after the cleanliness of Candida albicans biofilm.

\section{Methods}

\section{Experimental Design}

RDL was used to reline water bath PMMA discs $(10 \times 1.5$ $\mathrm{mm})$. The initial SR data were measured and subsequently, specimens were disinfected. Prior the biofilm formation, specimens were exposed for $30 \mathrm{~min}$ to human whole saliva for acquired pellicle formation. And after the development of a 48 h Candida albicans biofilm, the specimens were randomly assigned to one of four cleansing process $(n=8)$ : alkaline peroxide with 3 or $15 \mathrm{~min}$ of immersion time, $0.5 \%$ sodium hypochlorite or distilled water as control. After, the specimens were sonicated to remove biofilm structure and the final SR was measured.

\section{RDL discs}

A water bath PMMA resin (Lucitone 550, Denstply, De Trey, USA) was used to manufacture the base disc of specimens. The resin was packed in metal flasks and polymerized in a polymerizing unit (Termotron P-100; Termotron Equipamentos Ltd, Piracicaba, SP, Brazil) at $71^{\circ} \mathrm{C}$ for $9 \mathrm{~h}$, according to the manufacture's recommendations. All flasks were allowed to bench cooling for at least $3 \mathrm{~h}$ and the samples were removed. The PMMA base discs were finished and stored in deionized water for $48 \mathrm{~h}$ at room temperature $\left(23 \pm 1.0^{\circ} \mathrm{C}\right)$ for monomer release $(10)$.

For the RDL specimens, the base discs received a PMMA-based (Coe Soft, GC America; Alsip, IL, USA) or a silicone-based (Ufi Gel P, Voco; Cuxhaven, Germany) RDL layer with $1.5 \mathrm{~mm}$ of thickness leading to a final thickness of $3.0 \mathrm{~mm}$. The $1.5 \mathrm{~mm}$ uniform liner layer was performed by inserting them into a glass mould, pouring the denture liner, placing glass slides over it and firmly fixing both ends, then separating the glass plates after material curing $(8,11)$. These specimens were finished according to manufacturer's recommendation and used immediately.

\section{Surface roughness}

The RDL SR was measured using a profilometer (Surfcorder SE 1700 Kozaka Industry, Kozaka, Japan) with a $0.01 \mu \mathrm{m}$ resolution, calibrated at sample length of $0.8 \mathrm{~mm}$, $3.2 \mathrm{~mm}$ measurement pathway, and velocity of $0.5 \mathrm{~mm} / \mathrm{s}$. Three readings were taken for each sample, and the average was calculated (10).

After the record of initial surface roughness data, the specimens were disinfected by ultrasonic bath for $20 \mathrm{~min}$ (12) and stored in pre-sterilized, polystyrene, flat-bottomed 24-well tissue plates for saliva pellicle formation.

\section{Saliva pellicle formation}

All specimens received a salivary pellicle coating prior to biofilm development in order to simulate the mouth conditions. Human whole saliva was collected from a single healthy volunteer, who had not used antibiotics, mouth rinses, or any other medication known to affect salivary composition and flow in the past 3 months, and who provided written informed consent previously approved by the Local Ethics Committee. Stimulated saliva was collected and clarified by centrifugation at $10,000 \mathrm{~g}$ for $10 \mathrm{~min}$ at $4^{\circ} \mathrm{C}$. The supernatant was sterilized by $0.22 \mu \mathrm{m}$ membrane filtration (TPP, Trasadingen, Switzerland) and $1 \mathrm{~mL}$ of sterile saliva was placed into each well of sterile 24-well tissue plates with the RDL specimens, which remained there for $30 \mathrm{~min}$ to form an acquired pellicle (12). After this period, specimens were removed, washed twice with sterile PBS and immediately used in the biofilm development assay. 


\section{Candida albicans biofilm assay}

C. albicans ATCC 90028 was aerobically cultured at $35^{\circ} \mathrm{C}$ for $24 \mathrm{~h}$ on Sabouraud Dextrose Agar (SDA) and a loopful of growth was inoculated into Yeast Nitrogen Base (YNB) broth (Difco Laboratories, Detroit, MI, USA) supplemented with $50 \mathrm{mM}$ glucose. After 18 to $20 \mathrm{~h}$ of incubation, cells were washed twice with PBS and suspended in YNB supplemented with $100 \mathrm{mM}$ glucose, and standardized to $10^{7}$ cell $/ \mathrm{mL}$ ascertained spectrophotometrically (12).

Biofilm was developed on RDL surface placed inside sterilized flat-bottomed 24-well tissue plates. Aliquots of 2.0 $\mathrm{mL}$ of standard cell suspensions of yeasts were transferred into each well with one disc and incubated for $90 \mathrm{~min}$ at $35^{\circ} \mathrm{C}$ in an orbital shaker (Lab-line Incubator Shaker, Elliott Bay Laboratory Services, USA) at $75 \mathrm{rpm}$ (adhesion phase). After the adhesion phase, the cell suspension was gently aspirated and each specimen was washed twice with PBS. For biofilm phase, $2.0 \mathrm{~mL}$ of freshly YNB supplemented with $100 \mathrm{mM}$ glucose was added to each well and the plates were incubated for $48 \mathrm{~h}$ at $35^{\circ} \mathrm{C}$ at $75 \mathrm{rpm}$ in an orbital shaker as described before. At the end of each $24 \mathrm{~h}$ of incubation the medium was aspirated and specimens were washed with PBS followed by the addition of freshly $2.0 \mathrm{~mL}$ medium.

\section{Cleansing Treatment}

After $48 \mathrm{~h}$ of biofilm development, the specimens were assigned to one of four cleansing treatment: POL (enzymatic alkali peroxide; Polident 3-minutes, GlaxoSmithKline; Philadelphia, PA, USA); EFF (alkali peroxide; Efferdent,
Warner Lambert Co.; Morris Plains, NJ, USA); HYP (disinfectant; $0.5 \%$ sodium hypochlorite, Proderma Pharmacy, Piracicaba, Brazil) or DW (distilled water) used as control. All cleansing processes were performed with $8 \mathrm{~mL}$ of the solution, allowing all surfaces of the specimens to be in contact with the cleanser. The POL and EFF were prepared in distilled deionized water following the manufacturer's directions. The period of immersion in the denture cleanser was established according the manufacturer's instruction, $3 \mathrm{~min}$ for POL and $15 \mathrm{~min}$ for EFF. Specimens were immersed for 10 min into cleaner treatment with the HYP. For DW, the specimens remained $15 \mathrm{~min}$ as a reference for the higher time used by EFF.

\section{Statistical analysis}

All analyses were performed using the SAS software (SAS Institute Inc., version 9.0, Cary, NC, USA) employing a significant level fixed at $5 \%$. The normality of errors distribution and the degree of non-constant variance were checked for the response variable (13). All data were analyzed using two-way ANOVA, considering the RDL materials and the cleansing treatments as study factors and SR as the response variable. The Tukey HSD test was used as post ANOVA.

\section{Results}

There was no difference between the cleansing treatments in respect to their effects on surface roughness $(P>0.05$; Fig. 1).

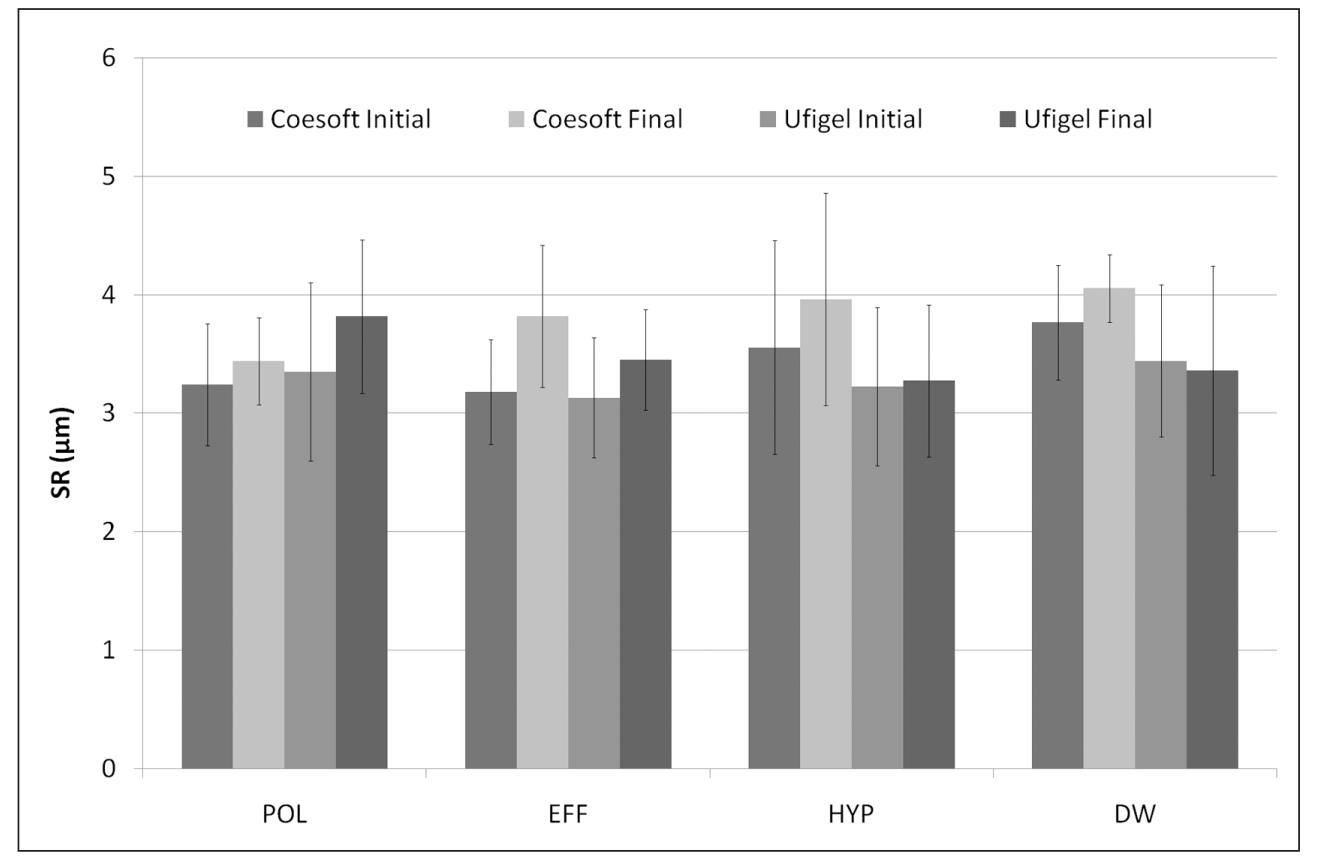

Fig. 1. Surface roughness of RDLs before and after the cleansing treatment (mean \pm standard deviation; $n=8$ ). 
Considering all sample, the PMMA-based RDL present higher SR than silicone-based at all evaluations $(P<0.001$, Table 1). Regardless the cleansing treatments, the SR increased after the treatments in comparison to the baseline values $(P<0.001$, Table 1$)$.

Table 1. Surface roughness before and after the cleansing treatments.

\begin{tabular}{lcc}
\hline & Baseline & Final \\
\hline PMMA-based & $3.43 \pm 0.58 \mathrm{Aa}$ & $3.82 \pm 0.54 \mathrm{Ab}$ \\
Silicone-based & $3.29 \pm 0.64 \mathrm{Ba}$ & $3.48 \pm 0.65 \mathrm{Bb}$ \\
\hline
\end{tabular}

Uppercase letters indicate significant difference between RDL materials and lowercase letters indicate significant difference between the baseline and the final SR values $(P<0.001)$.

\section{Discussion}

A wide range of denture cleansers are available in the health market; however, similar products have different immersion times recommended by the manufacturers. They control the biofilm, but they may also cause significant surface deterioration as well (14). The effectiveness of these products against Candida spp. biofilms was previously evaluated, showing a limited power of disinfection independently of their immersion time (15).

However, the effect of different immersion time on surface properties has not been evaluated. It is important, since the material deterioration may be related to the increase of SR associated with surface irregularities, such as cracks and pits found in RDL, providing a larger surface area and a more sheltered environment for biofilm development, which protect microorganisms from being removed by the subsequent cleansing treatments (16).

According to Kazanji and Watkinson (17) the RDL loses soluble components, such as ethanol and ester plasticizers (dibutyl phthalate) of PMMA-based liners, to the solution in which they are immersed. A solution with higher ionic concentration (potassium and sodium), such as some denture cleansers, could lead to a higher release of these components than distilled water $(17,18)$. However, in the present study, no differences were found between the cleansing treatments, neither to the group submitted to immersion in distilled water.
In the present study, there was no difference between the surface integrity of both RDL after the cleansing treatments. The decreased polymerization level of a RDL processed in a chairside manner, as both liners used in this study, causes spaces between polymers or surface porous that results in a more susceptible surface to hardening by the loss of ethanol and plasticizer components and the water absorption (19). Eventually the RDLs cease to protect the tissue and may even cause trauma rather than relieve it by their surface alterations.

Also, in the present study, the silicon-based RDL presented a smoother surface than PMMA-based, in which this SR difference may be attributed to their difference of composition; since it was used a methodology to manufacture the sample with SR values in the same range reported by others studies $(6,16,20)$.

There was found higher SR after all the treatments, either for the group submitted to immersion in distilled water, compared to the baseline values. This result disagrees from Harrison, Basker and Smith (21), who reported that denture cleansers can affect differently the RDL surface. A previous study (22) reported that immersion of RDL in water for seven days promoted an increase of SR higher than immersion in an alkaline peroxide cleanser and suggested that the water uptake phenomenon is more important than the loss of soluble components. The present results corroborates that the surface deterioration is more influenced by the time of immersion than by the time of denture cleansers (9), independently of the RDL composition and peroxide concentration of the solutions.

However, the immersion in water solution during $48 \mathrm{~h}$ for Candida spp. biofilm development could overlap the effect of the denture cleansers on surface, since the ethanol (penetrating agent) present in PMMA-based RDL can be lost after its immersion in water for $24 \mathrm{~h}$ by difference of osmotic pressure (9). Additionally, studies with longer periods of assessment must be conducted with the purpose of assessing material degradation in relation to its structural loss.

Within limitations of this study, it can be concluded that the surface roughness of PMMA and silicone-based RDLs increased after all treatments, independently of the immersion time recommended by the manufacturer.

References

1. Benting DG, Pesun IJ, Hodges J. Compliance of resilient denture liners immersed in effervescent denture cleansers. J Prosthodont 2005;14:175-83.

2. Malmstrom HS, Mehta N, Sanchez R, Moss ME. The effect of two different coatings on the surface integrity and softness of a tissue conditioner. J Prosthet Dent 2002;87:153-7.

3. Murata $H$, Iwanaga $H$, Shigeto $N$, Hamada $T$. Initial flow of tissue conditioners--influence of composition and structure on gelation. J Oral Rehabil 1993;20:177-87.

4. Murata H, Hamada T, Taguchi N, Shigeto N, Nikawa H. Viscoelastic properties of tissue conditioners--influence of molecular weight of polymer powders and powder/liquid ratio and the clinical implications. J Oral Rehabil 1998;25:621-9.

5. Nikawa H, Yamamoto T, Hamada T, Sadamori S, Agrawal S. Cleansing efficacy of commercial denture cleansers: ability to reduce Candida albicans biofilm activity. Int J Prosthodont 1995;8:527-34 
6. Nevzatoglu EU, Ozcan M, Kulak-Ozkan Y, Kadir T. Adherence of Candida albicans to denture base acrylics and silicone-based resilient liner materials with different surface finishes. Clin Oral Investig 2007;1 1:231-6.

7. Coulthwaite L, Verran J. Potential pathogenic aspects of denture plaque. Br J Biomed Sci 2007;64:180-9.

8. Nikawa $H$, Yamamoto $T$, Hamada $T$, Rahardjo MB, Murata $H$. Commercial denture cleansers--cleansing efficacy against Candida albicans biofilm and compatibility wit soft denture-lining materials. Int J Prosthodont 1995;8:434-44.

9. Murata $\mathrm{H}$, Chimori $\mathrm{H}$, Hong $G$, Hamada T, Nikawa $\mathrm{H}$. Compatibility of tissue conditioners and denture cleansers: Influence on surface conditions. Dent Mater J 2010 ;29:446-53.

10. Lima EM, Moura JS, Del Bel Cury AA, Garcia RC, Cury JA. Effect of enzymatic and $\mathrm{NaOCl}$ treatments on acrylic roughness and on biofilm accumulation. J Oral Rehabil 2006;33:356-62

11. Ferreira MA, Pereira-Cenci T, Rodrigues de Vasconcelos LM, Rodrigues-Garcia RC, Del Bel Cury AA. Efficacy of denture cleansers on denture liners contaminated with Candida species. Clin Oral Investig 2009;13:237-42.

12. da Silva WJ, Seneviratne J, Samaranayake LP, Del Bel Cury AA. Bioactivity and architecture of Candida albicans biofilms developed on poly(methyl methacrylate) resin surface. J Biomed Mater Res B Appl Biomater 2010;94:149-56.

13. Box GEP, Hunter JS, Hunter WG. Statistics for experimenters: design, innovation and discovery. 2nd.ed. New York:John Wiley and Sons Inc.; 2005.

14. Nikawa $H$, Iwanaga $H$, Hamada $T$, Yuhta $S$. Effects of denture cleansers on direct soft denture lining materials. J Prosthet Dent 1994;72:657-62.

15. Vieira AP, Senna PM, Silva WJ, Del Bel Cury AA. Long-term efficacy of denture cleansers in preventing Candida spp. biofilm recolonization on liner surface. Braz Oral Res 2010;24:342-8

16. Radford DR, Sweet SP, Challacombe SJ, Walter JD. Adherence of Candida albicans to denture-base materials with different surface finishes. J Dent 1998;26:577-83.

17. Kazanii MN, Watkinson AC. Soft lining materials: their absorption of, and solubility in, artificial saliva. Br Dent J 1988;165:91-4

18. Graham BS, Jones DW, Sutow EJ. An in vivo and in vitro study of the loss of plasticizer from soft polymer-gel materials. J Dent Res 1991;70:870-3.

19. Gronet PM, Driscoll CF, Hondrum SO. Resiliency of surface-sealed temporary soft denture liners. J Prosthet Dent 1997;77:370-4.

20. Nikawa $H$, Hamada $T$, Yamamoto $T$, Kumagai $H$. Effects of salivary or serum pellicles on the Candida albicans growth and biofilm formation on soft lining materials in vitro. J Oral Rehabil 1997;24:594-604.

21. Harrison A, Basker RM, Smith IS. The compatibility of temporary soft materials with immersion denture cleansers. Int J Prosthodont 1989;2:254-8.

22. Garcia RM, Leon BT, Oliveira VB, Del Bel Cury AA. Effect of a denture cleanser on weight, surface roughness, and tensile bond strength of two resilient denture liners. J Prosthet Dent 2003;89:489-94. 